\title{
Carbonate-clastic sediments of the Dudziniec Formation in the Kościeliska Valley (High-Tatric series, Tatra Mountains, Poland): role of syndepositional tectonic activity in facies development during the Early and Middle Jurassic
}

\author{
Anna JEZIERSKA ${ }^{1, *}$, Piotr ŁUCZYŃSKI ${ }^{1}$ and Alicja STAŚKIEWICZ ${ }^{1}$ \\ 1 University of Warsaw, Faculty of Geology, Żwirki i Wigury 93, 02-089 Warszawa, Poland
}

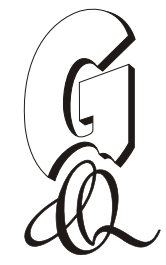

\begin{abstract}
Jezierska, A., Łuczyński, P., Staśkiewicz, A., 2016. Carbonate-clastic sediments of the Dudziniec Formation in the Kościeliska Valley (High-Tatric series, Tatra Mountains, Poland): role of syndepositional tectonic activity in facies development during the Early and Middle Jurassic. Geological Quarterly, 60 (4): 869-880, doi: 10.7306/gq.1327

Sediments of the Dudziniec Formation (Lower Jurassic - Aalenian) outcropping in the Kościeliska Valley (autochthonous unit of the High-Tatric series) are represented by a range of mixed carbonate-clastic deposits. Seven lithofacies have been distinguished based on lithology, sedimentary structures, colour and composition of intra- and extraclasts, with sandstones and crinoidal limestones as end members of a continuous spectrum of facies. The study area represents a shallower part of the sedimentary basin located in the vicinity of source areas, as compared to the Chochołowska Valley region located in the west. Facies characteristics and distribution were controlled mainly by synsedimentary tectonic activity, with sandy varieties representing periods of faulting with enhanced influx of extraclasts, and with crinoidal limestones corresponding to intervals of relative tectonic stability. Such influence of synsedimentary tectonics on the deposition in the Early Jurassic strongly resembles the Middle Jurassic development in the High-Tatric area. Neptunian dykes cutting the Dudziniec Formation, and most probably filled by Lower Jurassic sediments, are yet another indication of tectonic instability of the area in the Early Jurassic.
\end{abstract}

Key words: carbonates, clastics, synsedimentary tectonics, Dudziniec Formation, Lower and Middle Jurassic, Tatra Mts.

INTRODUCTION

Syndepositional tectonic activity was an essential factor affecting sedimentation in the Alpine-Carpathian region during the Early and Middle Jurassic. Intensity of tectonic processes, related to rifting and opening of new ocean basins, varied between particular parts of the Western Tethys. As a result of opening of the Penninic-Vahic Ocean, the Alpine-Carpathian region became separated from the stable Palaeo-Europe continent (Plašienka et al., 1997; Csontos and Vőrős, 2004). The prevailing extensional regime led to disintegration of Triassic carbonate platforms occupying the northern shelf of the Tethys Ocean and to formation of fault-bounded blocks, which were subjected to uplift or subsidence (Michalík, 1994; Wieczorek, 1995; Dumont et al., 1996; Santantonio and Carminati, 2011; Plašienka, 2012). Symptoms of Jurassic syndepositional tectonic activity are best known from the Alps (Winterer and Boselini, 1981; Blendinger, 1984, 1986; Bertok et al., 2011) and the Apennines (Santantonio, 1993; Cozzi, 2000; Marino and Santantonio, 2010). Jurassic deposits of the Tatra Mountains also show much evidence of

* Corresponding author, e-mail: aj.jezierska@gmail.com

Received: July 15, 2016; accepted: September 16, 2016; first published online: November 18, 2016 such activity (Uchman, 1994; Łuczyński, 2001a, 2002; Jach, 2007; Jezierska and Łuczyński, 2016).

The effect of tectonic activity on sedimentation in the High-Tatric series has been described in detail for the Middle Jurassic (Łuczyński, 2001a, 2002; Jezierska and Łuczyński, 2016). Considering the fact that disintegration of the northern carbonate shelf of the Tethys began already in the Early Jurassic, the Lower Jurassic sequences of the High-Tatric series should also show evidence of such activity. However, in spite of a number of unsolved questions, the Lower Jurassic of the Tatra Mountains has not been studied in detail for decades. Studies performed in the 1920s and the 1950s focused on a general description of lithology, petrology and fauna (Horwitz and Rabowski, 1922; Kotański, 1959; Radwański, 1959a), and on the character of the contact between the Triassic and the Lower Jurassic in the Smytnia Valley (Radwański, 1959b). Later studies focused on the Lower Jurassic in the Chochołowska Valley (Wójcik, 1981). The author pointed to an important relation between syndepositional tectonic activity and deposition of the Lower Jurassic sediments. Also recent studies on unconformities between the Triassic and the Jurassic (Jezierska and Łuczyński, 2016) confirmed that tectonic activity was an important factor affecting the Early Jurassic sedimentation. The Lower and Middle Jurassic deposits of the High-Tatric domain have much in common. The aim of this paper is to evaluate the influence of syndepositional tectonic activity on facies development in the High-Tatric series of the Tatra Mountains during deposition of the Dudziniec Formation. 


\section{GEOLOGICAL SETTING}

The Tatra Mountains are the northernmost of the so-called core mountains of the Central Western Carpathians (Fig. 1A). They consist of a Variscan crystalline core and a Permo-Mesozoic sedimentary cover which is divided into two major successions or series: (i) High-Tatric and (ii) Sub-Tatric (Fig. 1B), differing in completeness and facies development. The High-Tatric succession is represented mainly by shallow-water deposits with numerous stratigraphic gaps, whereas the Sub-Tatric succession is represented mainly by deeper-marine facies. According to Andrusov et al. (1973), these series correspond respectively to the Tatric Unit (i) and to the Fatric and Hronic units (ii), referred to as the major palaeogeographic units of the Central Western Carpathians.

The High-Tatric succession crops out in three tectonic units: Kominy Tylkowe, Czerwone Wierchy and Giewont (Fig. 1B; Kotański, 1961). The Kominy Tylkowe Unit is also referred to as the autochthonous unit, as its deposits rest directly on the crystalline basement. The unit embraces also the paraautochthonous folds, with sediments detached from basement and moved over small distances, but palaeogeographically still representing the same area. The Czerwone Wierchy and Giewont units, referred to also as allochthonous or foldic units, are detached from basement and thrust northwards over the autochthonous unit to form the High-Tatric nappes (Jurewicz, 2005, 2012). Therefore, palaeogeographically, the allochthonous units represent areas located south of the Kominy Tylkowe series.
The Jurassic deposits of the High-Tatric series are arranged into lithostratigraphic units: the Dudziniec Formation (Lower Jurassic to the lowermost Middle Jurassic - Aalenian), the Smolegowa Formation (Bajocian), the Krupianka Formation (Bathonian) and the Raptawicka Turnia Formation (Callovian-Hauterivian; Lefeld et al., 1985; Fig. 2).

The Lower Jurassic Dudziniec Formation occurs only in the Kominy Tylkowe Unit and rests on various Triassic strata (predominantly Rhaetian). It is represented mainly by sandy-crinoidal facies (Wójcik, 1981). Detrital material contains quartz grains, carbonate lithoclasts and bioclasts (bivalves, crinoids, brachiopods and belemnites). Age of the formation has been determined as Hettangian-Aalenian (Horwitz and Rabowski, 1922; Wójcik, 1981; Lefeld et al., 1985). Several members or beds are distinguished within the formation (Lefeld et al., 1985; Fig. 3):

- Kopieniec Starorobociański Bed - thin and medium-bedded, grey, dark grey or blue-grey sandy limestones;

- Kobyla Głowa Limestone Member - medium-bedded, dark grey encrinites with small amounts of clastic admixture;

- Kobylarka Limestone Member - massive grey encrinites;

- Smytnia Limestone Member - poorly bedded grey to dark grey and black limestones containing brachiopods and bivalves;

- Iwanówka Limestone Member - thin to medium bedded, grey to black encrinites with an admixture of quartz, Tri-

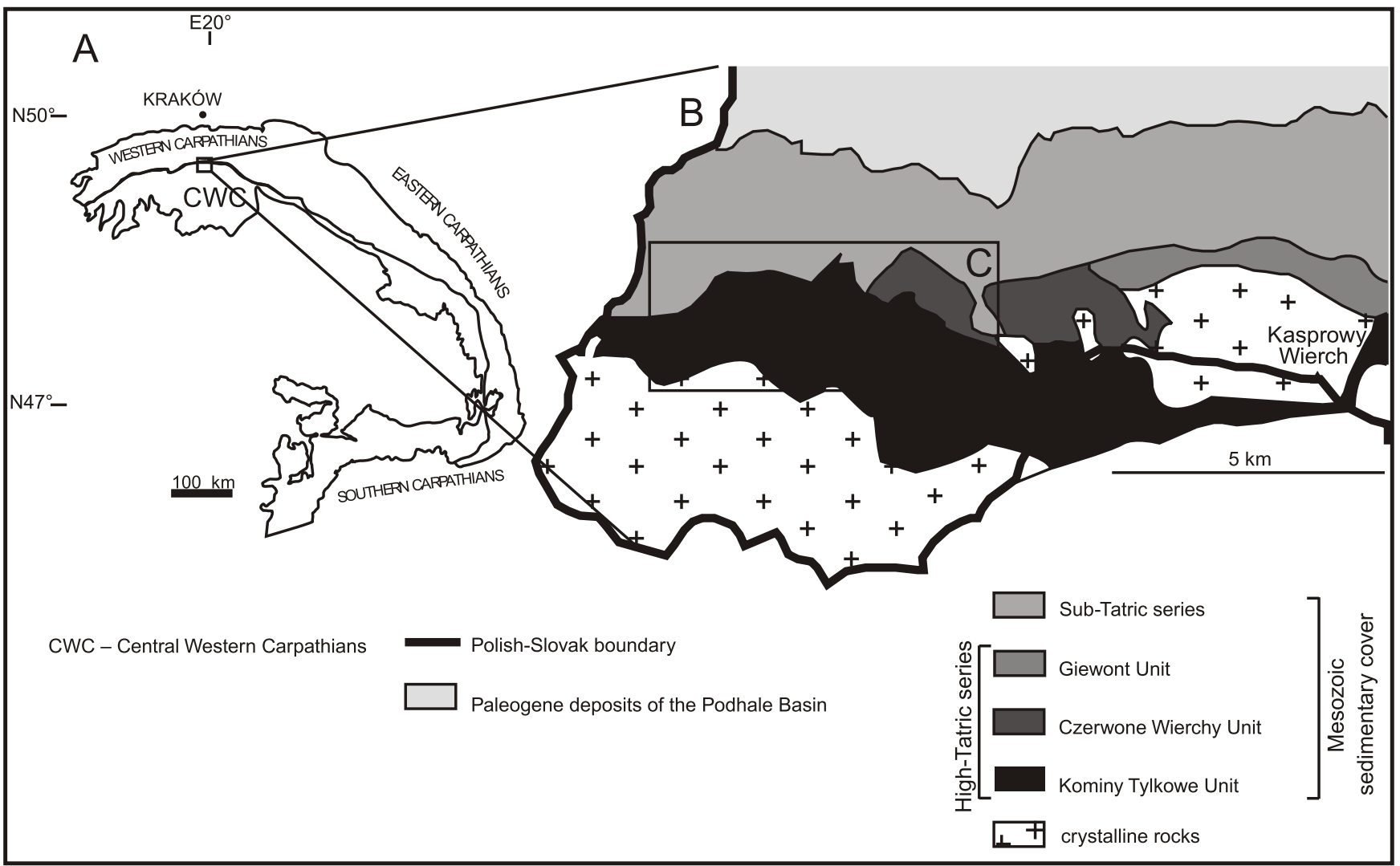

Fig. 1. Structural map of the western part of the Polish section of the Tatra Massif (B; after Łuczyński, 2001a), its geographical location within the Carpathians (A), and the position of the area enlarged on Figure 4 (C) 

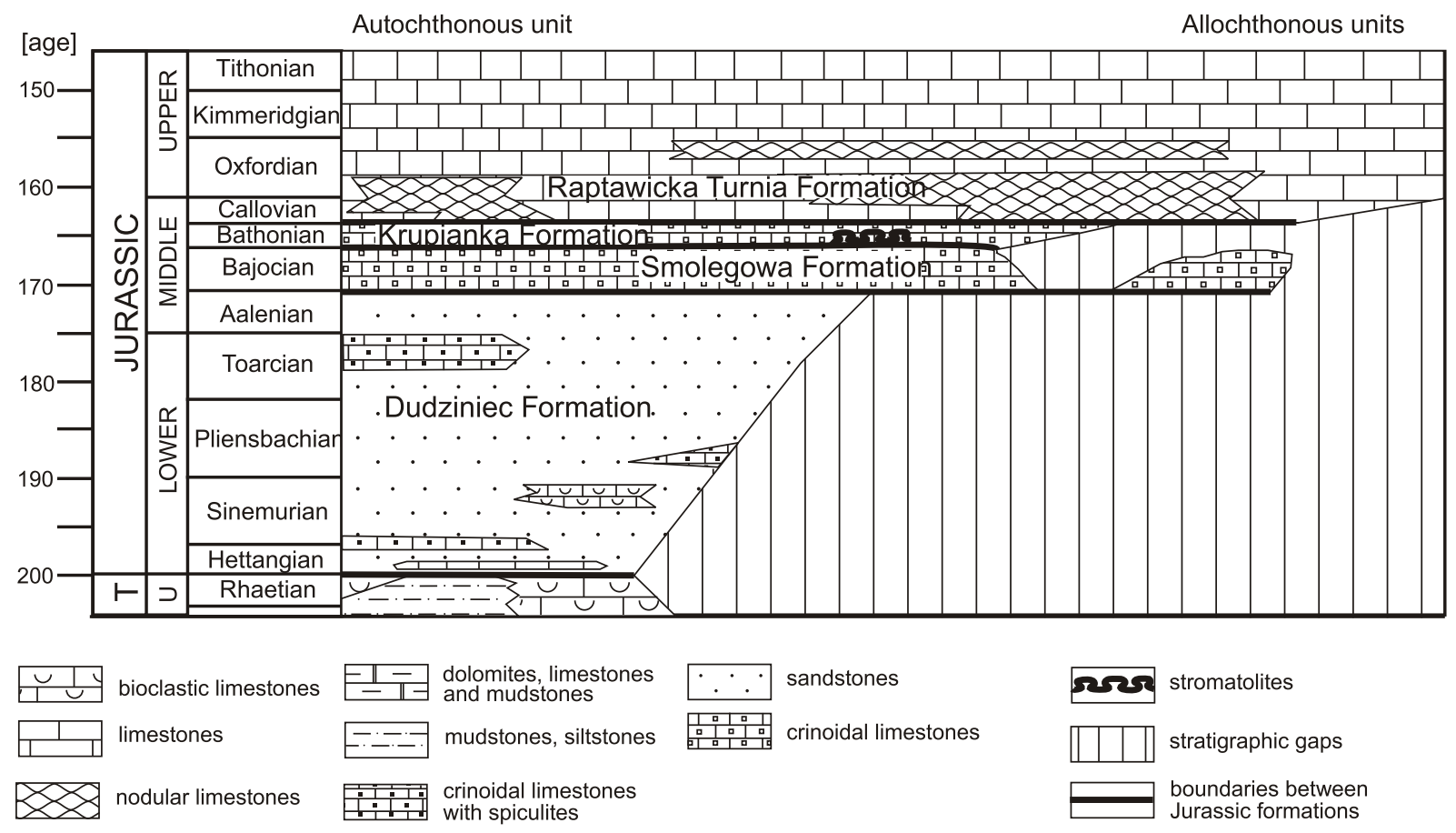

Fig. 2. General lithostratigraphy of the Jurassic in the High-Tatric series (after Uchman, 2014)

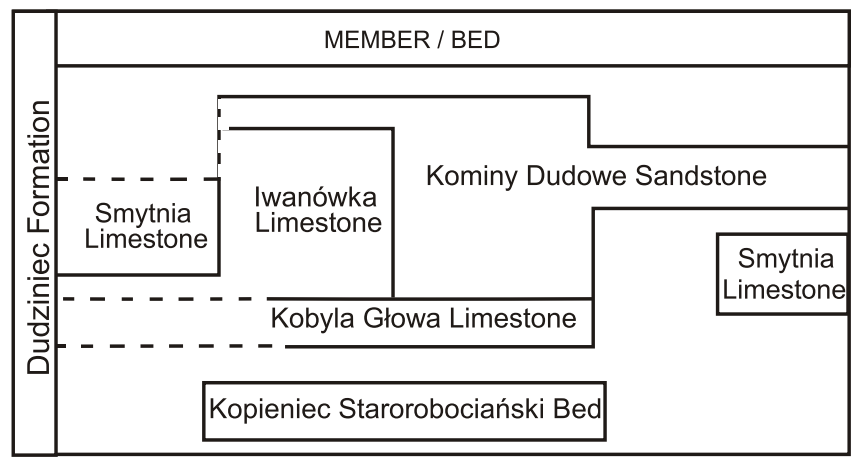

Fig. 3. Subdivision of the Dudziniec Formation (after Lefeld et al., 1985)

assic dolomites and spiculites composed of loose sponge spicules;

- Kominy Dudowe Sandstone Member - medium-bedded, light grey, pinkish-grey and yellowish conglomeratic-quartzitic sandstones, calcareous in places.

The Smolegowa Formation is represented by light grey or pinkish crinoidal limestones. Its age has been determined as Bajocian based on brachiopod fauna (Horwitz and Rabowski, 1922). The Krupianka Formation is developed as red and pink crinoidal limestones, nodular limestones and ferruginous limestones (Łuczyński, 2001b, 2002). Based on ammonite fauna its age has been determined as Bathonian (Passendorfer, 1935, 1938). The Raptawicka Turnia Formation embraces Callovian wavy bedded limestones and Oxfordian to Hauterivian massive limestones (Horwitz and Rabowski, 1922; Passendorfer, 1928; Lefeld et al., 1985).

The autochthonous unit represents the most complete succession of the High-Tatric series, whereas the paraauto- chthonous folds and the allochthonous units are less complete and contain numerous stratigraphic gaps. For example, in the Czerwone Wierchy Unit, the Anisian is directly overlain by the Smolegowa, Krupianka or even Raptawicka Turnia formations (e.g., Łuczyński, 2002).

\section{MATERIALS AND METHODS}

The study area is located in the upper part of the Kościeliska Valley, in the Western Tatra Mountains (Fig. 1C). Sediments of the Dudziniec Formation occur on both western and eastern slopes of the valley, between the Raptawicka Turnia crest and the Wąwóz Kraków Gorge in the north, and the Smytnia Valley in the south (Fig. 4). Most attention was paid to exposures located on the eastern slopes of the Kościeliska Valley, as they have not been described in detail so far. The Dudziniec Formation was studied on a bed-by-bed basis in six sections located on both sides of the Kościeliski Stream (Figs. 4 and 5).

The studied deposits of the Dudziniec Formation show a lithological variability, ranging from carbonates to clastics. The lithological complexes were defined based on such attributes as: lithology, colour, occurrence of sedimentary structures, composition, and size and sorting degree of extraclasts and intraclasts. Several lithofacies (lithological varieties) have been distinguished (Fig. 6).

Twenty-four thin-sections were prepared from the samples representing all the lithofacies. Due to a mixed carbonate-clastic character of the deposits, a combination of different classifications was applied to describe particular microfacies (Fig. 7). Microfacies of rocks containing $<50 \%$ of extraclasts were determined according to the Dunham (1962) classification. In all other cases, the predominant kind of groundmass (micritic matrix or non-carbonate/sparry groundmass) was determined first, and the applied classification was selected ac- 


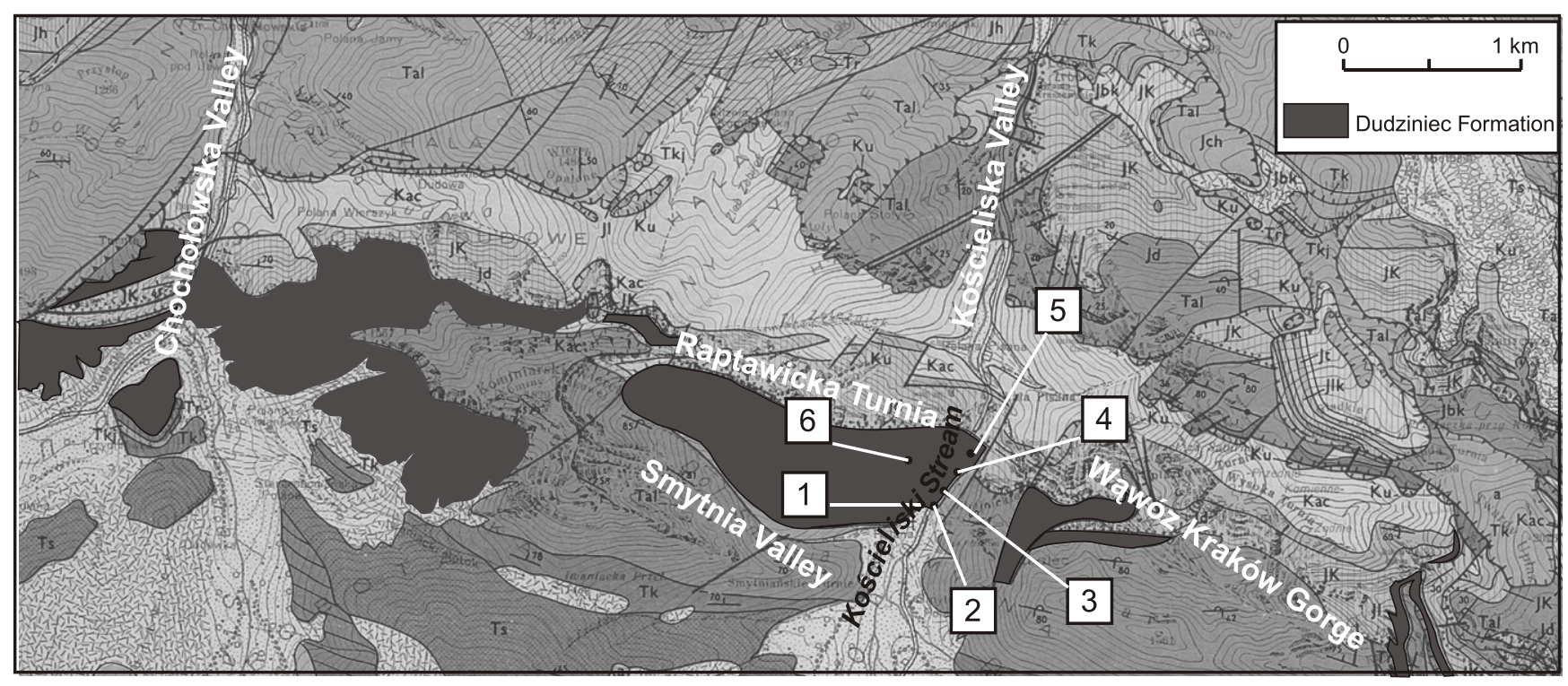

Fig. 4. Outcrops of the Dudziniec Formation in the Western Tatra Mountains (after Bac-Moszaszwili et al., 1979), with location of the sections studied

cordingly. In case of rocks with a micritic matrix, samples containing at least $15 \%$ of micrite were treated as carbonates and described using the Dunham (1962) classification. If the micrite content was $<15 \%$, the rocks were described according to the Zuffa (1980) classification. Rocks with a non-carbonate or sparry groundmass were described using the Pettijohn et al. (1972) classification. However, if the sample contained carbonate intraclasts, its microfacies was determined according to the Zuffa (1980) classification. Based on these classifications, several characteristic microfacies were distinguished within the Dudziniec Formation.

The proposed correlation of particular profiles (Fig. 5) is based mainly on field observations (bed to bed), spatial relations of particular complexes, and on the identification of macro- and microfacies.

\section{RESULTS}

In the study area, the lowest part of the Dudziniec Formation is represented by facies I (F I), developed as pinkish-grey/pinkish-white hybrid sandstones (composed of carbonate intra- and extraclasts and non-carbonate extraclasts), occurring in sections 1-3 (Figs. 5 nad 6A). In thin-sections the facies is represented by sparry hybrid arenites (Fig. $8 \mathrm{~A}$ and Table 1). In sections $1-4$, facies I is overlain by pinkish-purple sandy-pebbly limestones (Fig. 6) of facies II (F II), containing abundant debris of broken bivalve and brachiopod shells. Its microfacies corresponds to bioclastic-extraclastic wackestones (Fig. 8B and Table 1). Occurrence of Spiriferina (Fig. 6B; Spiriferina walcotti or Dispiriferina davidsoni) indicates its Late Sinemurian or Early Pliensbachian age (Haas, 1885; Siblik, 1965; Rousselle, 1977). The uppermost part of section 1 shows a lateral transition between facies F I and F II (Fig. 5). Facies II corresponds probably to Unit 1 distinguished by Horwitz and Rabowski (1922), dated as Early or Middle Sinemurian. Facies II is overlain by dark grey sandy-pebbly limestones (Fig. 6C) of facies III (F III), with abundant brachiopods and bivalves, in the thin-section represented by extraclastic-bioclastic packstones (Fig. 8C and Table 1). Fa- cies III occurs in sections 3 and 4 and corresponds to the Upper Sinemurian grey to dark grey and black limestones of the Smytnia Member (Lefeld et al., 1985). In section 3, these limestones are overlain by dark to light grey calcareous lithic sandstones (Fig. 6D) of facies IV (F IV), the microfacies of which has been determined as lithic arenites/sparry extraarenites (Fig. 8D and Table 1). Upwards, facies IV is gradually replaced by white to light grey siliceous pebbly sublithic sandstones (Fig. 6E) of facies $V(F \vee)$, with microfacies represented by siliceous sublithic arenites (Fig. 8E and Table 1). The facies probably corresponds to the Kominy Dudowe Member (Lefeld et al., 1985) dated as Pliensbachian (Horwitz and Rabowski, 1922). Facies VI and VII (F VI and F VII; Fig. 6F), developed respectively as: crinoidal limestones (VIA - crinoidal grainstones; Fig. 8F and Table 1), sandy crinoidal limestones (VIB - extraclastic-crinoidal grainstones; Fig. 8F and Table 1) and hybrid crinoidal sandstones (VII - crinoidal hybrid arenites; Fig. 8H and Table 1), occur in sections 5 and 6 between facies $V$ and the overlying Raptawicka Turnia Formation.

The Dudziniec Formation in the Kościeliska Valley is cut by neptunian dykes running obliquely or parallel to bedding, and characterized by variable width and various shapes (Fig. 6G). The dykes are filled by white, orange or red micrite with an admixture of small quartz grains; or by red hybrid arenite which is similar to the surrounding host rocks and contains quartz, feldspars, dolomicrite and microdolospars. In some cases the walls of fissures are covered with calcite cements.

\section{INTERPRETATION}

The studied deposits of the Lower Jurassic Dudziniec Formation are characterized by substantial lithological diversity. Variability of the sandy-crinoidal lithofacies (F I-F VII), differing mainly in the amount and character of clastic admixture, reflects changes of sedimentary conditions prevailing during deposition of particular facies. All the lithofacies have a mixed carbonate-clastic character, however, with distinctly different proportions of particular elements. 

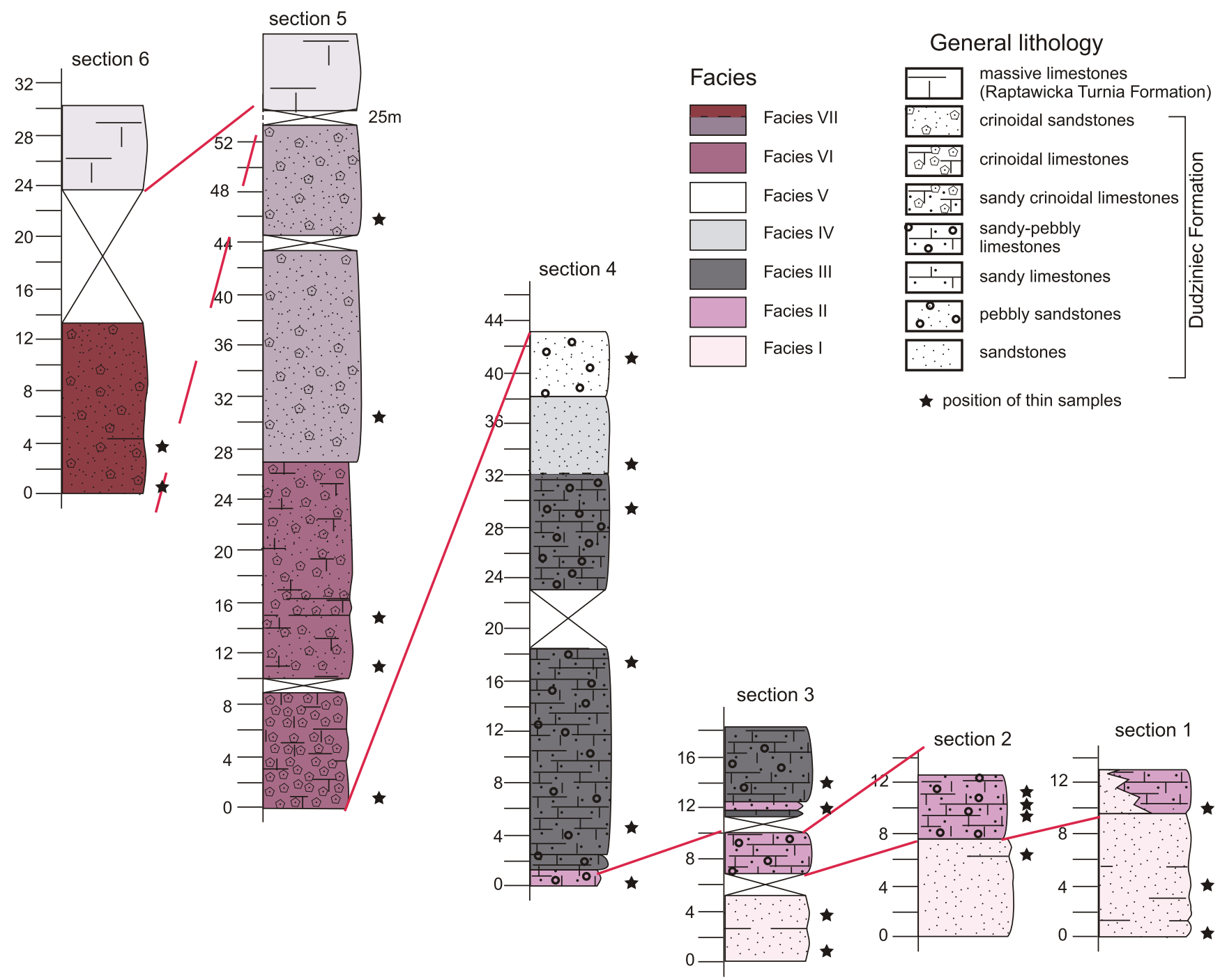

Fig. 5. Dudziniec Formation sections studied in the Kościeliska Valley

Deposition of sandstones (facies I, IV and V) took place in a shallow, high-energy environment. Clastic material was transported from uplifted blocks that were subjected to intense erosion. Various extraclasts come from multiple sources. Non-carbonate extraclasts (such as quartz and feldspars) most probably come from the eroded Keuper and Werfenian (Triassic) rocks of the High-Tatric domain. In the Czerwone Wierchy and Giewont units there is a substantial stratigraphic gap embracing the Upper Triassic and the Lower Jurassic. The same source has been suggested by Popiołek et al. (2010) for the Lower Jurassic deposits of the Križna Unit. Radwański (1959a), however, attributed such clasts to erosion of a crystalline massif, probably located further south (Low Tatra Mountains). In such case, due to a relatively large distance from source areas, only the most resistant grains (quartz) were transported into the part of the High-Tatric Basin today exposed in the Kościeliska Valley. On the other hand, the relatively large size of some dolomite extraclasts, which are generally characterized by relatively poor resistance to weathering, indicates that the area of deposition was in a close vicinity to elevated blocks built of Middle Triassic carbonate rocks. Radwański (1959b) described littoral structures in the Smytnia Valley (located west of the Kościeliska Valley), which are relics of an Early Jurassic cliff shore.
Crinoidal facies (F VI-VII) were deposited in a shallow-water environment, relatively far from land, during periods of tectonic stability. Best preserved crinoids are present in the crinoidal limestones (facies F VIA), in which they constitute $70-80 \%$ of rock volume. Crinoidal elements are unbroken, rounded and well-sorted. Generally, such crinoidal material is formed as a result of long-lasting winnowing leading to unification of their shapes and sizes (Blyth Cain, 1968). Therefore, sedimentation of the crinoidal facies most probably took place in a high-energy environment, in a zone located above crinoidal meadows (see Głuchowski, 1987). The sandy crinoidal limestones (facies F VIB) and the crinoidal sandstones (facies VII) contain a smaller amount of crinoidal material and an accordingly greater amount of extraclasts. Therefore, facies F VIB and F VII also represent a high-energy environment, but located closer to elevated source areas.

Periods of sedimentation of sandstones and crinoidal limestones were separated by episodes of mixed clastic-carbonate deposition represented by sandy limestones (facies F II and F III) with a relatively large amount of clastic admixture. The origin of such mixed carbonate-clastic sediments within the Dudziniec Formation can be attributed to a combination of such processes as: source mixing, storm mixing and facies mixing (Mount, 

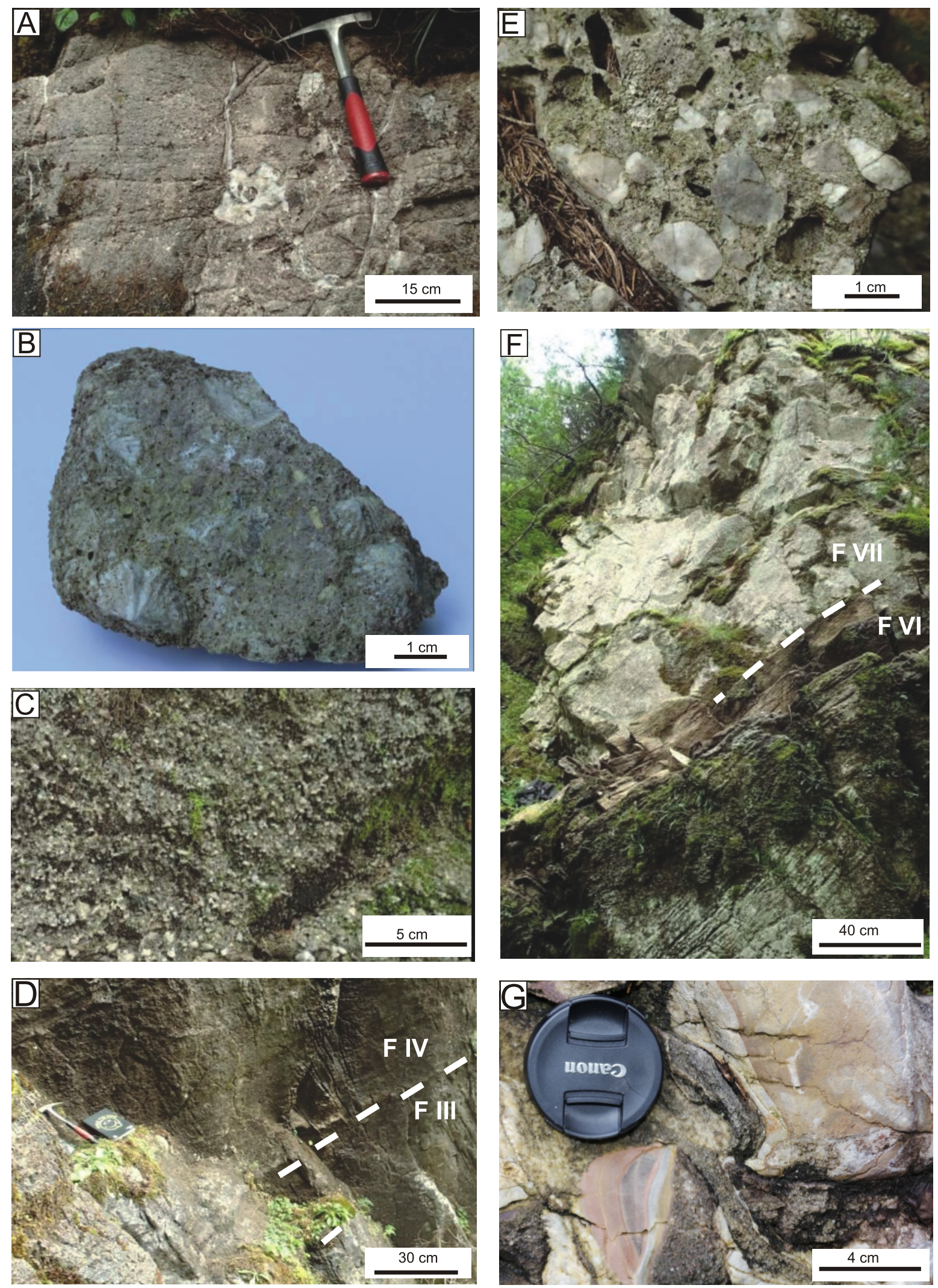

Fig. 6. Dudziniec Formation in the Kościeliska Valley

A - grey hybrid sandstone cut by a network of neptunian dykes partly infilled by white calcite cements (facies I, section 1); B grey sandy-pebbly limestone with ? Spiriferina sp. (facies II, section 2); C - dark grey sandy-pebbly limestone (facies III, section 3); D - gradual transition between dark grey sandy-pebbly limestone (facies III) and light grey calcareous lithic sandstone (facies IV, section 4); E - light grey siliceous pebbly sublithic sandstone (facies V, section 4); F - cherry sandy crinoidal limestones (facies VI) and light grey hybrid crinoidal sandstones (facies VII, section 5); G - neptunian dyke infilled by pink, orange and grey bands of micrite (calcilutite) and white calcite cements (facies II, section 2) 


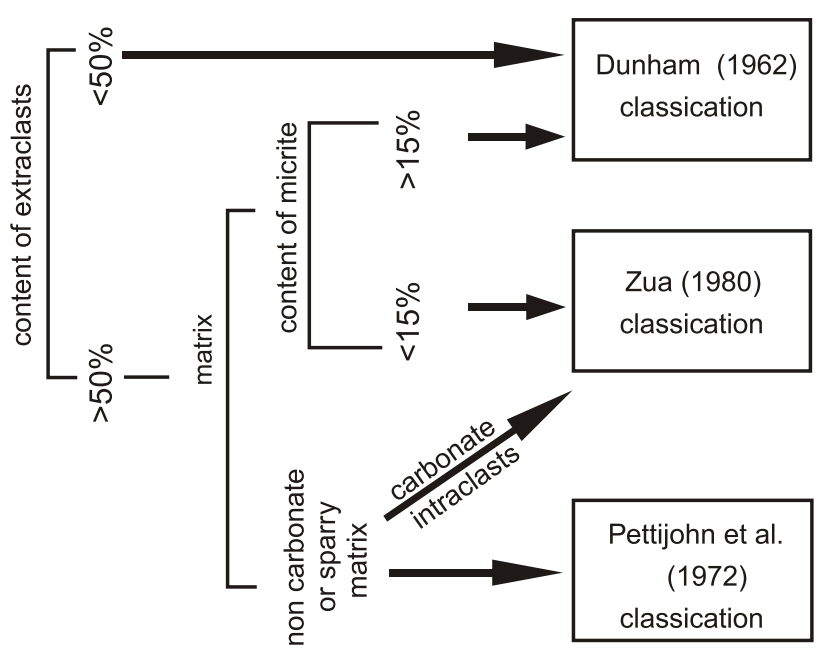

Fig. 7. Scheme illustrating the criteria of applying various classifications used to identify the microfacies of the mixed sandy-carbonate sediments

1984). Facies F II and F III, developed as sandy-pebbly limestones, contain abundant scattered shells of brachiopods and bivalves. These sediments probably formed as an effect of storm activity, which was responsible for an onshore transport of fauna from deeper parts of the basin. Facies F III show also graded bedding and contain characteristic large intraclasts. On the other hand, a large amount of clastic admixture is probably associated with erosion taking place on uplifted blocks. Facies mixing can also be observed in the studied sections (e.g., in mixing of facies $F$ I and $F$ II in section 1).

Wójcik (1981) analysed the deposits of the Dudziniec Formation in the Chochołowska Valley (a region located to the west of the study area), and divided their sedimentary history into a number of cycles. A complete cycle is composed of:

- quartzitic sandstones,

- mixed sediments consisting of quartz, peloids and crinoids,

- crinoidal limestones (containing sponge spicules).

$\mathrm{He}$ attributed the origin of the cycles to periodic, local syndepositional tectonic activity that led to an uplift of some blocks and to the resulting differentiation of bottom morphology. The uplifted blocks were subjected to intense erosion which caused an increase in the supply of clastic material and, in consequence, led to sedimentation of sandy facies. Crinoidal facies were deposited during periods of tectonic stability.

In the Kościeliska Valley, the development of the Dudziniec Formation is generally similar, but the cycles are not so well-developed, and all the distinguished lithofacies are characterized by a relatively considerable amount of clastic admixture. In the Chochołowska Valley region, the Dudziniec Formation sections contain also deeper facies represented by crinoidal limestones with sponge spicules. Moreover, the sedimentary record in this area seems to be continuous (with a continuous transition between the Dudziniec and the Smolegowa formations), which also indicates a relatively deeper environment, without episodes of emersion. All these features suggest that the study area was located in a close vicinity to source areas during the Early Jurassic, whereas the region of the Chochołowska Valley represents a deeper part of the basin.

All the above-presented attributes point to fluctuations in the intensity of erosion and of the clastic material input as the main factors controlling sedimentation of the Dudziniec Formation in the High-Tatric Basin. These, in turn, could be governed by such processes as: syndepositional tectonic activity, sea level fluctuations, and changes in climate and weathering conditions, or by the combinations of the above. The distance from source areas also played an important role in the facies spatial distribution. The Early Jurassic was a period of general eustatic sea level rise (Hallam, 2001), with transgression pulses in the Early Hettangian, Early Sinemurian, Early Pliensbachian and Early Toarcian. Generally, these pulses correspond to the occurrences of crinoidal facies in the studied sections of the Dudziniec Formation (Fig. 2), but without a precise stratigraphic control, a more detailed interpretation is impossible. The facies record of the formation does not, however, reveal the overall deepening trend, with shallow-water sandstone facies present in the whole lithological column. This suggests that local syndepositional tectonic activity, overprinting the global eustatic tendencies, must have been the decisive factor that controlled facies distribution. Plašienka (2012) related the occurrence of various coarse-grained Jurassic syn-rift sediments to the opening of the Vahic (South Penninic) Ocean during the Zliechov and Devín tectonic phases (Early and Late Liassic, respectively). Early Jurassic tectonic activity is reported from many Carpathian basins (e.g., Magura, Kysuca-Pieniny, Špirúň, Zliechov, North and South Tatric ridges), and apparently it also governed deposition of the studied sediments. Periods of tectonic activity and intense erosion of uplifted blocks were characterized by sedimentation of sandstones and sandy limestones, whereas periods of relative tectonic stability mark times of deposition of crinoidal facies. Climatic changes could also influence the intensity of weathering and erosion of elevated areas and thus control the amount of clastic material transported into the sedimentary basin, however, the exact mechanism of such influence is difficult to evaluate.

\section{DISCUSSION}

The detailed studies of the High-Tatric Lower Jurassic deposits in the Kościeliska Valley area, presented in this paper, contribute to the identification of environmental conditions and processes controlling sedimentation of the Dudziniec Formation. They also add new information to the general model proposed by Wójcik (1981). Because the Early to Middle Jurassic interval was a period of intense tectonic activity, the Lower Jurassic sedimentary record is obscured by numerous stratigraphic gaps in many places. In the High-Tatric series, the occurrence of the Dudziniec Formation (Hettangian-Aalenian) is limited only to the autochthonous unit, whereas in the Czerwone Wierchy and Giewont units, there is a stratigraphic gap embracing the Upper Triassic-Middle Jurassic interval. The attempt to reconstruct facies development during the Early Jurassic is a supplement to the palaeogeographical evolution of the High-Tatric domain presented by Łuczyński (2002) for the Middle Jurassic. Considering the development of the High-Tatric Lower and Middle Jurassic, and the processes taking place during these periods, the Dudziniec Formation and the Middle Jurassic formations (especially the Bajocian Smolegowa Formation and partly the Bathonian Krupianka Formation) reveal many similarities. On the other hand, comparable processes, mainly related to syndepositional tectonic activity, are somewhat differently manifested in the sedimentary record.

Both the Lower and Middle Jurassic formations are in whole or partly developed as crinoidal facies, differing in the content of crinoidal debris and the amount of clastic admixture. In the crinoidal limestones of the Dudziniec and Smolegowa forma- 

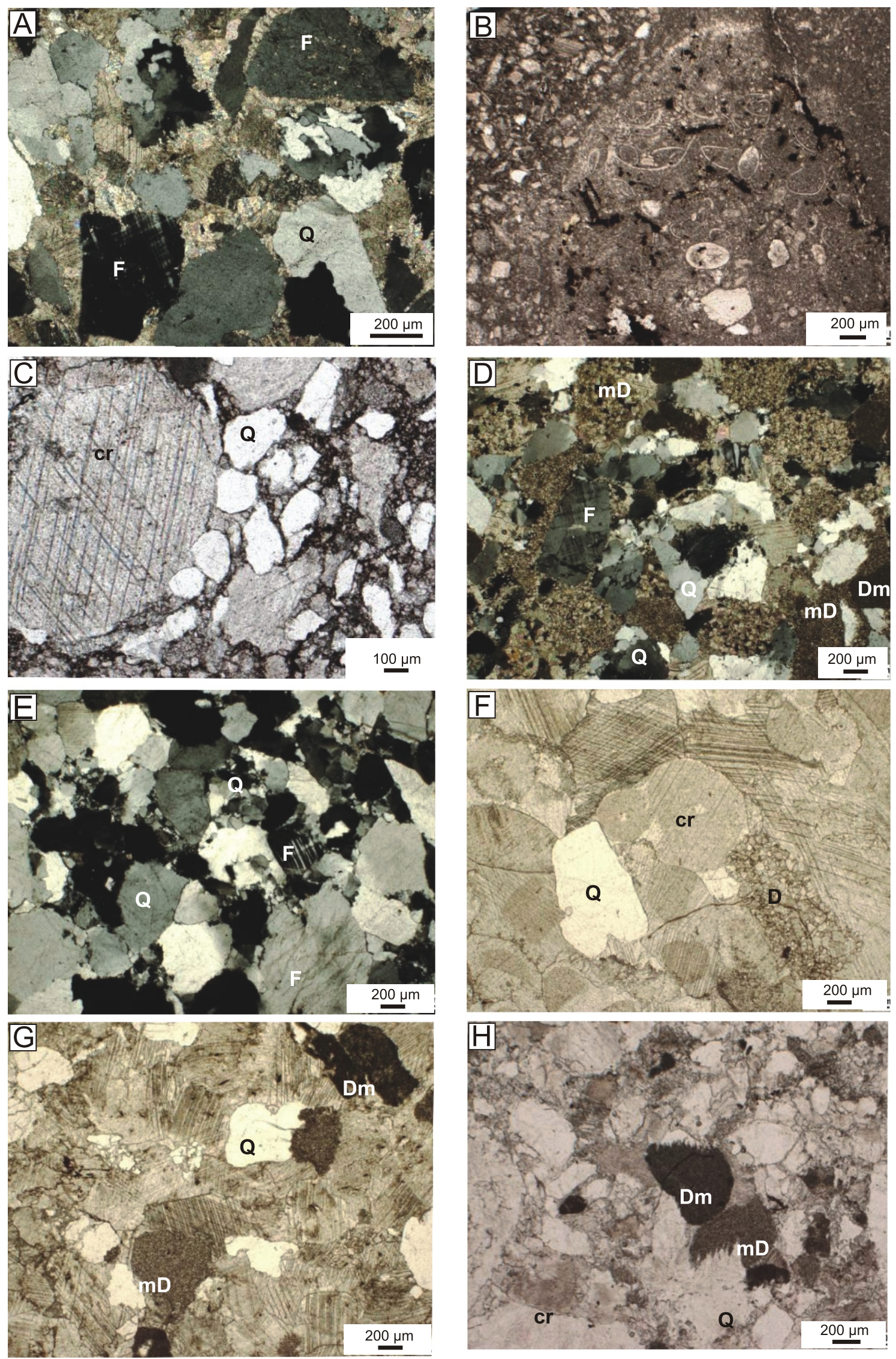

Fig. 8. Microfacies of the Dudziniec Formation

A - sparry hybrid arenite (facies I); B - bioclastic-extraclastic wackestone (facies II); C - extraclastic-bioclastic packstone (facies III); D - lithic arenite/sparry extraarenite (facies IV); $\mathbf{E}$ - sublithic arenite (V); $\mathbf{F}$ - crinoidal grainstone (facies VI); G - extraclastic-crinoidal grainstone (facies VI); H - crinoidal hybrid arenite (facies VII); Q - quartz, F - feldspar, Dm - dolomicrite, $\mathrm{mD}$ - microdolospar, D - dolospar, cr - crinoid 
Facies of the Dudziniec Formation distinguished in the sections

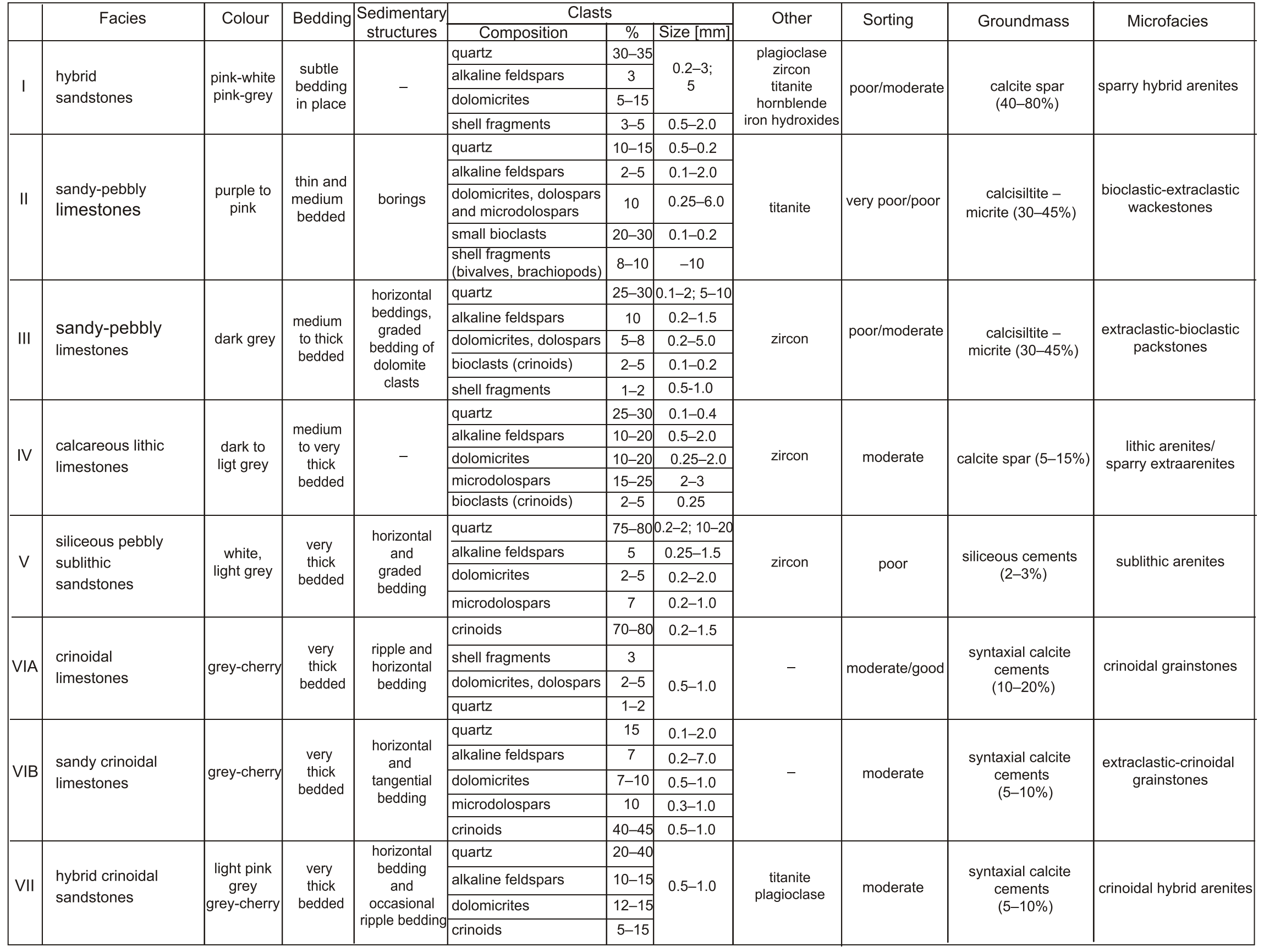


tions, the crinoidal material constitutes over $80 \%$ of rock volume and forms almost pure encrinites. However, apparently similar facies correspond to slightly different environments. Crinoidal limestones of the Smolegowa Formation represent a zone of in situ accumulation of crinoidal meadows, which is indicated by well-preserved large crinoidal fragments with a small amount of terrigenous admixture (Głuchowski, 1987; Łuczyński, 2002). For the crinoidal limestones of the Dudziniec Formation, Wójcik (1981) suggested a position below the crinoidal meadows, based on the occurrence of sponge spicules. Such kind of crinoidal facies occurs in the Chochołowska Valley region. In the Kościeliska Valley area, the crinoidal limestones contain well-preserved, unbroken and relatively large crinoidal fragments, however, supplemented by small amounts of clastic admixture. Most probably, they represent a zone located above the crinoidal meadows, but still in a relatively low-energy environment. The Krupianka Formation (Bathonian) is also partly developed as crinoidal limestones, with the content of crinoidal material ranging between 30 and $80 \%$ (Łuczyński, 2002), and a relatively most abundant clastic admixture. This facies resembles the sandy crinoidal limestones of the Dudziniec Formation. In both cases, the accumulation of crinoid ossicles took place above the crinoidal meadows, in a shallow and probably high-energy environment. Intense supply of clasts points to proximity to elevated and eroded areas.

The Lower and Middle Jurassic formations of the High-Tatric series either occur as discontinuous lenticular bodies (Łuczyński, 2002), or their record is obscured by visible internal breaks in deposition (Jezierska and Łuczyński, 2016). In contrast to the Dudziniec Formation, the Smolegowa and the Krupianka formations occur in the whole High-Tatric area (Giewont and Czerwone Wierchy autochthonous units). In the case of the Smolegowa Formation, a uniform sedimentation of crinoidal limestones took place in the whole High-Tatric Basin (Łuczyński, 2002). In areas where the Bajocian is absent in the normal stratigraphic succession, the Smolegowa Limestones can be found as infillings of neptunian dykes cutting the underlying Triassic rocks (Łuczyński, 2001a). Sedimentation of the Krupianka Formation also took place in the whole High-Tatric area, however, its deposits are preserved only as a very discontinuous cover, mostly limited to erosional depressions or present only as infillings of neptunian dykes. In the case of the Dudziniec Formation, there is no evidence of its occurrence anywhere outside of the autochthonous (Kominy Tylkowe) unit. Moreover, in the allochthonous units there is a complete lack of the Upper Triassic and Lower Jurassic due to intense erosion in this area. The most probable scenario is that sedimentation of the Lower Jurassic deposits took place only in the Kominy Tylkowe Unit, whereas the Czerwone Wierchy and Giewont units were elevated source areas (comp. Wieczorek, 1995; Dumont et al., 1996). Radwański (1959a) suggested that supply of clastic material to the Lower Jurassic deposits was from the south, which may correspond to the allochthonous High-Tatric units. Numerous clasts characterized by poor resistance to weathering, such as dolomites, indicate proximity of the source of clastic material. The lack of a continuous cover of Lower Jurassic deposits in this area (which are absent, e.g., in the paraautochthonous unit exposed on the slopes of Ciemniak, east of the Kościeliska Valley) is an effect of two main processes: syndepositional tectonic activity leading to the diversification of sea-floor morphology, and subsequent, pre-Bajocian erosion.

Another important issue concerns the differentiation of bottom morphology during the Early and the Middle Jurassic. A significant part of Jurassic deposits of the Kominy Tylkowe Unit reveals pronounced lithofacies variations along the $E-W$ line. Such diversity noted in the Dudziniec Formation (emphasized mainly by the amount of clastic admixture and occurrence of spiculites) suggests that the autochthonous basin was inclined westwards. The eastern part of the Kominy Tylkowe Unit, represented by sections in the Kościeliska Valley and in the paraautochthonous folds, was the shallowest part of the basin, located in close vicinity of source areas, whereas the western part of the unit (Chochołowska Valley) represented its deeper and more distal part. The Liassic transgression at first embraced the western part of the autochthonous unit and gradually continued eastwards. Facies differentiation disappeared during the Bajocian. Unified sedimentation of the Smolegowa crinoidal limestones took place in the whole High-Tatric region, and even the syndepositional tectonic activity did not lead to substantial facies diversification. Renewed differentiation of bottom morphology took place in the Bathonian, when the whole High-Tatric area became divided into fault-bounded blocks. The Kominy Tylkowe Basin became once again inclined to the west, which is indicated by local differences in the development of the Krupianka Formation. In the Rzędy pod Ciemniakiem region (eastern part of the Kominy Tylkowe Unit), the Bathonian is represented by shallow-water crinoidal limestones, whereas in the Chochołowska Valley on the west, the Bathonian is developed as deep-water nodular limestones (Łuczyński, 2002). Moreover, only in the western part of the autochthonous unit, sedimentation at the Bajocian/Bathonian boundary was not interrupted.

Both the Early and Middle Jurassic of the High-Tatric series are associated with the development of neptunian dykes. The most abundant and best examined dykes cutting the Triassic are filled with Middle Jurassic deposits (Łuczyński, 2001a), although Radwański (1959b) recorded also fissures filled by Lower Jurassic deposits. The voids filled by the Smolegowa and Krupianka formations differ in terms of their origin and infilling processes. Neptunian dykes developed in the Bajocian have a tectonic origin, which is indicated mainly by their sharp walls and regular orientation of fissures. In most cases, opening of voids probably took place already after deposition of loose crinoidal material of the Smolegowa Formation, by its injection into fissures opening in a lithified Triassic substrate. The origin of neptunian dykes filled by the Krupianka Formation is more complex and involves both tectonic and karstic processes, leading to the formation of dykes characterized by smooth walls and complex geometries. The mechanism of their infilling was also different. In this case, crinoidal sand transported on the sea bottom in the form of megaripples, filled the already opened fissures cutting the substrate.

Neptunian dykes occur also within the Dudziniec Formation. Great variety and complexity of shapes, and variable character of walls (from smooth to sharp-edged) suggest their complex origin. Most probably, the voids opened as a result of tectonic activity, but later were subjected to dissolution processes. The dykes are filled mainly by white to red micrite - most probably sieved sediments of the Dudziniec Formation. Walls of some fissures are covered by calcite cements, which occur also as bands separating particular portions of internal sediment. The presence of calcite cements indicates that the process of infilling of dykes was multi-stage, with time breaks between the opening of voids and their infilling. The occurrence of dykes filled by deposits of the Dudziniec Formation, and cutting the Lower Jurassic, indicates that development of the neptunian dykes in the High-Tatric region took place also in the Early Jurassic.

The Early and Middle Jurassic together constitute a distinct phase in the history of evolution of the High-Tatric series. Syndepositional tectonic activity, associated with the prevailing extensional regime, controlled sedimentation during the whole interval, which resulted in facies similarities between the 
Dudziniec, Smolegowa and Krupianka formations. Some influence of synsedimentary tectonics on deposition started already in the Late Triassic (Feist-Burkhardt et al., 2008; Jaglarz, 2010). The whole interval clearly differs in its development from the preceding and following phases of High-Tatric series evolution, characterized by relatively calm tectonic conditions.

\section{CONCLUSIONS}

Detailed studies of the Lower Jurassic Dudziniec Formation in the Kościeliska Valley area, confrontation of the results with those from earlier works devoted mainly to the Chochołowska Valley region, and comparison of the sedimentary development of the Kominy Tylkowe Unit during the Early and Middle Jurassic, allow the following general conclusions:

- The Dudziniec Formation in the Kościeliska Valley area is represented by a wide array of sandy-carbonate facies, with sandstones and crinoidal limestones as end members of a continuous spectrum, with seven distinct lithological varies (lithofacies) distinguished.

- The Kościeliska Valley area, which is located in the eastern part of the autochthonous unit, represents a shallower and a more proximal part of the basin than the areas located further on the west (Chochołowska Valley).

- The main factors governing the development and distribution of facies were the synsedimentary tectonic activity and distance from source areas (with sandy facies representing periods of block faulting and tectonic instability, and crinoidal facies corresponding to episodes of deposition in relatively stable conditions).

- The development of neptunian dykes filled with Jurassic deposits in the High-Tatric Basin started already in the Early Jurassic.

- The Early and Middle Jurassic together constitute a distinct phase in the history of High-Tatric series evolution, characterized by strong influence of synsedimentary tectonics on deposition.

Acknowledgements. The authors wish to express their gratitude to the authorities of the Tatra National Park (Poland) for permission to conduct fieldwork and to collect samples. We also wish to thank the journal reviewers: $R$. Jach, T. Rychliński and P. Jaglarz for their valuable and helpful comments, and to J. Szulc for his editorial handling. An important part of the paper summarizes the conclusions of A. Staśkiewicz's M.Sc. thesis prepared at the Faculty of Geology, University of Warsaw.

\section{REFERENCES}

Andrusov, D., Bystricky, J., Fusan, O., 1973. Outline of the structure of the Western Carpathians. Guide-book for the geological excursion, $X$ Congress of the Carpathian-Balkan Geological Association: $8-15$.

Bac-Moszaszwili, M., Burchart, J., Iwanow, A., Jaroszewski, W. Kotański, Z., Lefeld, J., Mastella, L., Ozimkowski, W., Roniewicz, P., Skupiński, A., Westwalewicz-Mogilska, E., 1979. Mapa geologiczna Tatr Polskich, 1:30 000 (in Polish). Wyd. Geol., Warszawa.

Bertok, C., Martire, L., Perotti, E., d'Atri, A., Piana, F., 2011. Middle-Late Jurassic syndepositional tectonics recorded in the Ligurian Briançonnais succession (Marguareis-Mongioie area, Ligurian Alps, NW Italy). Swiss Journal of Geosciences, 104: 237-355.

Blendinger, W., 1984. Late Ladinian strike-slip tectonics of the Marmolada-Costabella area (Dolomites). Jahrbuch der Geologischen Bundesanstalt, 127: 37-319.

Blendinger, W., 1986. Isolated stationary carbonate platforms: the Middle Triassic (Ladinian) of the Marmolada area, Dolomites, Italy. Sedimentology, 33: 159-184.

Blyth Cain, J.D., 1968. Aspects of the depositional environment and palaeoecology of crinoidal limestones. Scottish Journal of Geology, 4: 191-208.

Cozzi, A., 2000. Synsedimentary tensional features in Upper Triassic shallow-water platforms carbonates of the Carnian Prealps (northern Italy) and their importance as paleostress indicators. Basin Research, 12: 134-146.

Csontos, L., Vörős, A., 2004. Mesozoic plate tectonic reconstruction of the Carpathians region. Palaeogeography, Palaeoclimatology, Palaeoecology, 210: 1-56.

Dumont, T., Wieczorek, J., Boullin, J.P., 1996. Inverted Mesozoic rift structures in the Polish Western Carpathians (High-Tatric units). Comparison with similar features in the Western Alps. Eclogae Geologicae Helvetiae, 89: 181-202.

Dunham, R.J., 1962. Classification of carbonate rocks according to depositional texture. AAPG Memoir, 1: 108-121.
Feist-Burkhardt, S., Götz, A.E., Szulc, J., Borkhataria, R., Geluk, M., Haas, J., Hornung, J., Jordan, P., Kempf, O., Michalik, J., Nawrocki, J., Reinhardt, L., Ricken, W., Röhling, H.G., Rüffer, T., Török, A., Zühlke, R., 2008. Triassic. In: The Geology of Central Europe, 2: Mesozoic and Cenozoic (ed. T. McCann): 749-821. Geological Society, London.

Głuchowski, E., 1987. Jurassic and Early Cretaceous articulate Crinoidea from the Pieniny Klippen Belt and the Tatra Mountains, Poland. Studia Geologica Polonica, 94: 1-102.

Haas, H., 1885. Étude Monographique et Critique des Brachiopodes Rhétiens et Jurassiques des Alpes Vaudoises et des Centrées Environnantes. Mémoires de la Société Paléontologique Suisse, 11: 1-66.

Hallam, A., 2001. A review of the broad pattern of Jurassic sea-level changes and their possible causes in the light of current knowledge. Palaeogeography, Palaeoclimatology, Palaeoecology, 167: 23-37.

Horwitz, L., Rabowski, F., 1922. Sur le Lias et le Dogger haut-tatriques de la Tatra (in Polish with French summary). Posiedzenie Naukowe Państwowego Instytutu Geologicznego, 3: 15-18.

Jach, R., 2007. Bositra limestones - a step towards radiolarites: case study from the Tatra Mountains. Annales Societatis Geologorum Poloniae, 77: 161-170.

Jaglarz, P., 2010. Facies and sedimentary environment of the carbonate-dominated Carpathian Keuper from the Tatricum domain results from the Dolina Smytnia valley (Tatra Mts, Southern Poland). Annales Societatis Geologorum Poloniae, 80: 147-161.

Jezierska, A., Łuczyński, P., 2016. Jurassic unconformities in the High-Tatric succession, Tatra Mountains, Poland. Geological Quarterly, 60 (2): 273-290.

Jurewicz, E., 2005. Geodynamic evolution of the Tatra Mts. and the Pieniny Klippen Belt (Western Carpathians): problem and comments. Acta Geologica Polonica, 55: 295-338.

Jurewicz, E., 2012. Nappe-thrusting processes in the Tatra Mts. (in Polish with English summary). Przegląd Geologiczny, 60: 432-451. 
Kotański, Z., 1959. Stratigraphical sections of the high-Tatric series in the Polish Tatra Mountains (in Polish with English summary). Biuletyn Instytutu Geologicznego, 139: 71-60.

Kotański, Z., 1961. Tectogénèse et reconstruction de la paléogéographie de la zone haut-tatrique dans les Tatras (in Polish with French summary). Acta Geologica Polonica, 11: 187-476.

Lefeld, J., Gaździcki, J., Iwanow, A., Krajewski, K., Wójcik, K., 1985. Jurassic and Cretaceous lithostratigraphic units of the Tatra Mountains. Studia Geologica Polonica, 84: 1-93.

Łuczyński, P., 2001a. Development history of Middle Jurassic neptunian dykes in the High-Tatric series, Tatra Mountains, Poland. Acta Geologica Polonica, 51: 237-252.

Łuczyński, P., 2001b. Pressure-solution and chemical compaction of condensed Middle Jurassic deposits, High-Tatric series, Tatra Mountains. Geologica Carpathica, 52: 91-102.

Łuczyński, P., 2002. Depositional evolution of the Middle Jurassic carbonate sediments in the High-Tatric succession, Tatra Mountains, Poland. Acta Geologica Polonica, 52: 365-378.

Marino, M., Santantonio, M., 2010. Understanding the geological record of carbonate platform drowning across rifted Tethys margin: examples from the Lower Jurassic from Apennines and Sicily (Italy). Sedimentary Geology, 225: 116-137.

Michalík, J., 1994. Notes on the paleogeography and paleotectonics of the Western Carpathians Area during the Mesozoic. Mitteilungen Österreichisches Geologisches Gesellschaft, 86: 101-110.

Mount, J.F., 1984. Mixing of siliciclastic and carbonate sediments in shallow shelf environments. Geology, 12: 432-435.

Passendorfer, E., 1928. Le Kimeridgien dans la Tatra (in Polish with French summary). Sprawozdania Państwowego Instytutu Geologicznego, 4: 491-499.

Passendorfer, E., 1935. Studien über die Stratigraphie und die Paläontologie des hochtatrischen Jura in Tatry, I (in Polish with German summary). Rocznik Polskiego Towarzystwa Geologicznego, 11: 83-103.

Passendorfer, E., 1938. Étude sur la stratigraphie et paléontologie du Jurassique hauttatrique dans les Tatras, II (in Polish with French summary). Prace Towarzystwa Przyjaciół Nauk w Wilnie, 12: 1-9.

Pettijohn, F.J., Potter, P.E., Siever, R., 1972. Sand and Sandstones. Springer, New York.

Plašienka, D., 2012. Jurassic synrift and Cretaceous synorogenic, coarse-grained deposits related to opening and closure of the Vahic (South Penninic) Ocean in the Western Carpathians - an overview. Geological Quarterly, 56 (4): 601-628.
Plašienka, D., Grecula, P., Putiš, M., Kováč, M., Hovorka, D., 1997. Evolution and Structure of the Western Carpathians: an Overview. Mineralia Slovaca - Monograph: 67-72.

Popiołek, M., Salata, D., Uchman, A., 2010. Petrography and provenance of Lower Jurassic sandstones of the Med'odoly Sandstone Formation in the Križna Unit of the Kopy Sołtysie region in the Tatra Mountains (in Polish with English summury). Przegląd Geologiczny, 58: 154-162.

Radwański, A., 1959a. Z badań nad petrografią liasu wierchowego (in Polish). Przegląd Geologiczny, 7: 359-362.

Radwański, A., 1959b. Littoral structures (cliff, clastic dikes and veins, and borings of Potamilla in the High-Tatric Lias (in Polish with English summary). Acta Geologica Polonica, 9: 31-280.

Rousselle, L., 1977. Spiriférines du Lias moyen et supérieur au Maroc (Rides Prérifaines; Moyen Atlas) et en Espagne (Chaine Celtibérique orientale). Notes du Service Geologique du Maroc, 38: $153-175$.

Santantonio, M., 1993. Facies associations and evolution of pelagic carbonate platform/basin system: examples from the Italian Jurassic. Sedimentology, 40: 1039-1067.

Santantonio, M., Carminati, E., 2011. Jurassic rifting evolution of the Apennines and Southern Alps (Italy): parallels and differences. GSA Bulletin, 123: 468-484.

Siblik, M., 1965. Some new Liassic brachiopods. Geologický Sborník Slovenskej Akadémie Vied, 16: 1-264.

Uchman, A., 1994. Lower Jurassic carbonate sedimentation controlled by tilted blocks in the Choč unit in the Tatra Mts., Poland. Zentralblatt für Geologie und Paläontologie, (7): 875-883.

Uchman, A., 2014. Introduction - sedimentary rocks of the Tatra Mountains. In: Sedimentary Rocks of the Tatra Mountains (eds. R. Jach, T. Rychliński and A. Uchman): 12-28. Wydawnictwa Tatrzańskiego Parku Narodowego, Zakopane.

Wieczorek, J., 1995. Mesozoic evolution of the Tatra Mts. (Western Carpathians). Special Publications of the Geological Society of Greece, 4: 138-142.

Winterer, E.L., Bosellini, A., 1981. Subsidence and sedimentation of a Jurassic passive continental margin, Southern Alps. Italy. AAPG Bulletin, 65: 394-421.

Wójcik, K., 1981. Facies development of the vicinity of the Chochołowska Valley (in Polish with English summary). Przegląd Geologiczny, 39: 405-410.

Zuffa, G.G., 1980. Hybrid arenites: their composition and classification. Journal of Sedimentary Petrology, 50: 21-29. 